The diffusion coefficient, $D_{1,2}$, was obtained by the following equation, $H u=2 D_{1,2}+C u^{2}$. The experimental values of $H$ and flow rate $u$, about 10 to 20 points, were substituted in above equation to obtain $D_{1,2}$ which was calculated by the method of leastsquares.

Liquid samples, $0.5 \mu l$, and gas samples, $0.2 \mathrm{ml}$, were injected as solutes into column. The pressure in the column was equal to atmosphere pressure. Column temperature was changed from $115^{\circ} \mathrm{C}$ to $225^{\circ} \mathrm{C}$. As the carrier gas of organic vapor, carbon tetrachloride vapor was used. The flow rate of carrier gas was calculated by the retention time, and its flow rate was fixed between $1 \sim 4 \mathrm{~cm} / \mathrm{sec}$.

As the diffusion coefficient of carbon tetrachloride vapor in helium carrier gas was nearly equal to that of helium in carbon tetrachloride carrier vapor, it was assumed that the carrier vapor of carbon tetrachloride flowed through the column without disturbance.

Diffusion coefficients of methane, ethane, propane, $n$-butane, $n$-pentane, $n$-hexane, $n$-heptane in carbon tetrachloride vapor atmosphere were determined at $115 \sim 225^{\circ} \mathrm{C}$. The experimental values of $D$ were compared with the theoretical values calculated from the equations of Chen-Othmer, Giddings and Hirschfelder. As $D$ was proportional to $T^{b}$, the temperature dependence power, $b$, was about 1.7 for lower hydrocarbons-carbon tetrachloride.

As the $D s$ for hydrocarbons in carbon tetrachloride vapor atmosphere were nearly one-tenth of those in hydrogen or helium atmosphere, the gas chromatography using organic carrier vapor such as carbon tetrachloride could separate samples with high resolution, especially in a low flow rate of carrier vapor.

(Received Sept. 4, 1972)

\title{
鉛 8-ヒドロキシキノレート沈殿の性質
}

\author{
滝山一善，谷川 八千代，幸前 照美*
}

(1972 年 10 月 27 日受理)

鉛 8-ヒドロキシキノレート沈殿を常法と均一溶液からの沈殿法によって生成し, その性質について 検討した. 鉛 8-ヒドロギシキノレートの純水中における溶解度を測定して $7.6 \times 10^{-7} \mathrm{~mol} / l$ の值を得,

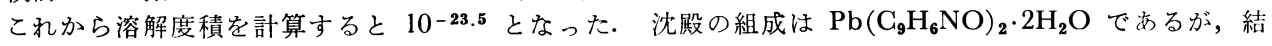
晶水を失いやすい. $110^{\circ} \mathrm{C}$ もくは高周波照射によって乾燥すると無水物として定量しうる. 沈殿は $\mathrm{pH} 7.5 \sim 12$ の範囲で定量的に生成し, 沈殿反応溶液を $100 \mathrm{ml}$ として 2 50 mg の鉛が常法で, 5〜 $50 \mathrm{mg}$ の鉛が均一溶液からの沈殿法で定量しうる. 常法による沈殿法によって沈殿の結晶核の大きさを 求めると，鉛 8-ヒドロキシキノレート分子約 2 個の集合体となった.

鉛 8-ヒドロキシキノレートは針状結晶と板状結晶の 2 形態を呈するが，前者が後者に比べてはるか に安定である. 針状結晶は正方晶系に属し $a_{0}=b_{0}=12.1 \AA, c_{0}=13.7 \AA$ である. 板状結晶はおそらく銅 8一ヒドロキシキノレートの板状結晶と同じく単斜晶系と考えられるが，明らかではない，沈殿生成に際 しては板状結晶がさきに生成し，これが針状結晶に転移する．転移は溶解析出によるいわゆる熟成過程 によるものと考えられる.

\section{1 緒 $\overrightarrow{\overline{\bar{n}}}$}

多くの金属 8-ヒドロキシキノレートは容易に定量的 沈殿を生成し，またひょう量形が得やすい. 鉛 8-ヒド ロキシキノレートは弱塩基性溶液から緑黄色の沈殿とし て生成するが, 温水に多少溶解し, 一定組成を得がた いとして従来鉛の重量分析法としては推奨されなかっ た1)2). しかし，8-アセトキシキノリンを用いる均一溶

* 武庫川女子大学家政学部 : 兵庫県西宮市池開町6-46
液からの沈殿法によれば容易に定量的かつ粗大な沈殿が 得られた. また鉛 8-ヒドロキシキノレートは銅きカド ミウム 8-ヒドロキシキノレートと同様に 針状結晶と板 状結晶の 2 形態を呈することがわかっだ). これら沈殿 の生成とその性質について述べる.

\section{2 実験}

\section{1 試薬}

金属溶液はすべて特級硝酸塩の水溶液とし, 重量分析 
もしくは EDTA 滴定法によって正確な濃度を求めた.

8一アセトキシキノリンは 8一ドロキシキノリンから 合成し4)，アセトンに溶かして $2 \%$ 溶液とした。

8-ヒドロキシキノリンはエチルアルコールから再結晶 したのち，エチルアルコールまたは酢酸（1:20）に溶 かし $2 \%$ 溶液とした.

緩衝液は酢酸, 酢酸ナトリウム, クエン酸ナトリウ ム, ホウ酸ナトリウム, 水酸化ナトリウムなどを使用し て種々の $\mathrm{pH}$ のも妾調製し, 使用条件でイオン強度が 約 0.1 となるようにした.

\section{2 使用機器}

pH メーター：東亜電波製 HM-5A.

ポーラログラフ：柳本製作所製 PA-1を使用し，25士 $0.5^{\circ} \mathrm{C}$ で $\tau=4.1 \mathrm{sec}, m=2.01 \mathrm{mg} / \mathrm{sec}$ の条件ですべて 水銀プールを対極とした.

光度滴定装置 : 柳本製作所製 PT-2 型.

原子吸光装置 : 日本ジャーレルアッシュ製 AA-1.

電子顕微鏡: 明石製作所製 Transcope TRS 80 WDC 特, 加速電圧 $100 \mathrm{kV}$.

高周波加熱乾燥機：松下電器産業製電子 レンジ $\mathrm{NE}$ 5600 .

\section{3 沈殿生成法}

常法による場合には 2〜 $50 \mathrm{mg}$ の鉛を含む溶液に $\mathrm{pH}$ 9 前後の緩衝液を加え全量 $100 \mathrm{ml}$ とし，2\% 8-ヒドロ キシキノリン溶液 $5 \mathrm{ml}$ を加え約 4 時間放置する. 均一 溶液からの沈殿法 (PFHS 法と略記) による場合には 5〜50 mg の鉛を含む溶液に $\mathrm{pH} 9$ 前後の緩衝液を加え 全量を $100 \mathrm{ml}$ とし， $2 \% 8$ 8アアセトキシキノリン溶液 $7 \mathrm{ml}$ を加えて 1 夜放置する.

\section{4 沪液中の鉛の定量}

沈殿の溶解損失を測定するため，鉛 8-ヒドロキシキ ノレート沈殿を生成させ，その沪液中の鉛を次のように して定量した.すなわち，沈殿を沪過洗浄した沪液およ び洗液を合わせて分液漏斗に入れ， $20 \mathrm{ml}$ のクロロホル ムを加えて 2 分間強く振り混ぜて 溶存していた鉛 8-七 ドロキシキノレートを抽出する. ついでクロロホルム層 に溶存している鉛を $0.1 N$ 硝酸 $10 \mathrm{ml}$ で逆抽出し，こ の抽出液中の鉛をポーラログラフ法で定量する.

なお，鉛 8-ヒドロキシキノレートの溶解度測定のた めに沈殿を純水および種々の $\mathrm{pH}$ の緩衝液（イオン強度 約 0.5) 中に懸濁し，ときどきかき混ぜながら約 $25^{\circ} \mathrm{C}$ の室内に 2 㡺夜放置し，これを沪過後沪液中の鉛を原子 吸光法によって定量した.

\section{3 実験結果および考察}

\section{1 鉛 8-ヒドロキシキノレート沈殿の溶解度}

鉛 8-ヒドロキシキノレートの針状結晶の 純水中にお ける溶解度を測定したところ, 鉛の濃度として 7.6× $10^{-7} \mathrm{~mol} / l$ となった. なお，平衡状態にある母液の $\mathrm{pH}$ は 7.6 となった. 8-ヒドロキシキノリンの酸解離定数 $K_{\mathrm{a}_{1}}=10^{-5} 13, K_{\mathrm{a}_{2}}=10^{-9.89}$ および鉛 8-ヒドロキシキノ リンの生成定数 $k_{1}=10^{9}, k_{2}=10^{85}$ ) を用い，鉛全濃度 $C_{\mathrm{Pb}}=7.6 \times 10^{-7}$ および 8 -ヒドロキシキノリン 全濃度 $C_{\mathrm{Q}}=2 \times 7.6 \times 10^{-7}$ の測定值から8-ヒドロキシキノレー トイオン濃度 [Q-]を次式によって求めた.

$$
\begin{aligned}
{\left[\mathrm{Q}^{-}\right]=\alpha_{2} C_{\mathrm{Q}} } & =\frac{K_{\mathrm{a}_{1}} K_{\mathrm{a}_{2}}}{\left[\mathrm{H}^{+}\right]^{2}+\left[\mathrm{H}^{+}\right] K_{\mathrm{a}_{1}}+K_{\mathrm{a}_{1}} K_{\mathrm{a}_{2}}} \times C_{\mathrm{Q}} \\
& =10^{-\mathbf{2 . 2 9}} \times 10^{-5.82} \\
& =10^{-8.11}
\end{aligned}
$$

鉛の全濃度は次式で表わされ，これから鉛イオン濃度 $\left[\mathrm{Pb}^{2+}\right]$ が求められる.

$$
\begin{aligned}
C_{\mathrm{Pb}} & =\left[\mathrm{Pb}^{2+}\right]+[\mathrm{PbQ}+]+\left[\mathrm{PbQ}_{2}\right] \\
& =\left[\mathrm{Pb}^{2+}\right]\left\{1+k_{1}\left[\mathrm{Q}^{-}\right]+k_{1} k_{2}\left[\mathrm{Q}^{-}\right]^{2}\right\} \\
{\left[\mathrm{Pb}^{2+}\right] } & =10^{-7.3}
\end{aligned}
$$

これらの值から鉛 8-ヒドロキシキノレートの溶解度 積 $K_{\mathrm{sp}}$ は次のように求められる.

$$
\begin{aligned}
K_{\text {sp }} & =\left[\mathrm{Pb}^{2+}\right]\left[\mathrm{Q}^{-}\right]^{2} \\
& =10^{-7.3} \times\left(10^{-8.11}\right)^{2} \\
& =10^{-23.5}
\end{aligned}
$$

ここに求められた溶解度積の值は亜鉛6)，カドミウ ム7), マグネシウム ${ }^{8)}$ などの 8-ヒドロキシキノレートの 溶解度積の值と比較して合理的であると考えられる.

溶解度積を用いて種々の $\mathrm{pH}$ における $\left[\mathrm{Pb}^{2+}\right]$, $\left[\mathrm{PbQ}^{+}\right],\left[\mathrm{PbQ}_{2}\right]$ の溶存量を次のようにして求めた. 鉛 8-ヒドロキシキノレートの溶解度を $S$, 解離した鉛 イオンの割合を $\beta$ とすれば

$$
\begin{aligned}
S & =C_{\mathrm{Pb}} \\
{\left[\mathrm{Pb}^{2+}\right] } & =\beta C_{\mathrm{Pb}} \\
& =\frac{1}{1+k_{1}\left[\mathrm{Q}^{-}\right]+k_{1} k_{2}\left[\mathrm{Q}^{-}\right]^{2}} \times C_{\mathrm{Pb}} \\
& =\frac{S}{1+2 k_{1} \alpha_{2} S+4 k_{1} k_{2} \alpha_{2}{ }^{2} S^{2}} \\
{\left[\mathrm{Q}^{-}\right] } & =\alpha_{2} C_{\mathrm{Q}}=2 \alpha_{2} S \\
K_{\mathrm{Sp}} & =\frac{4 \alpha_{2}{ }^{2} S^{3}}{1+2 k_{1} \alpha_{2} S+4 k_{1} k_{2} \alpha_{2}{ }^{2} S^{2}}
\end{aligned}
$$


上式から種々の $\mathrm{pH}$ において溶解度 $S$ を求め次式か ら各溶存種の濃度を求める.

$$
\begin{aligned}
{\left[\mathrm{Pb}^{2+}\right] } & =\beta S \\
{\left[\mathrm{PbQ}^{+}\right] } & =k_{1}\left[\mathrm{~Pb}^{2+}\right]\left[\mathrm{Q}^{-}\right] \\
& =2 k_{1} \alpha_{2} S\left[\mathrm{~Pb}^{2+}\right] \\
{\left[\mathrm{PbQ}_{2}\right] } & =k_{2}\left[\mathrm{PbQ}^{+}\right]\left[\mathrm{Q}^{-}\right] \\
& =k_{1} k_{2} K_{\mathrm{sp}}
\end{aligned}
$$

これらの計算結果を Fig. 1 に示す. また種々の $\mathrm{pH}$ における鉛 8-ヒドロキシキノレート飽和溶液から実測 して得られた溶解度をも Fig. 1 中に示した. Fig. 1 に 示したように溶解度積から求めた值と実測値はほぼ一致 している.

鉛 8-ヒドロキシキノレートの溶解度に対する温度の 効果を次のようにして求めた. 沈殿を沪過洗浄後 300 $\mathrm{m} l$ のフラスコ中で 純水に眯濁して 1 夜放置し, これを $25,50,80^{\circ} \mathrm{C}$ の恒温そう中でかき混ぜながら7時間保 ち懸濁液を沪過し，沪液中の鉛を抽出しポーラログラ フ法によって測定した.この結果を Table I に示す.

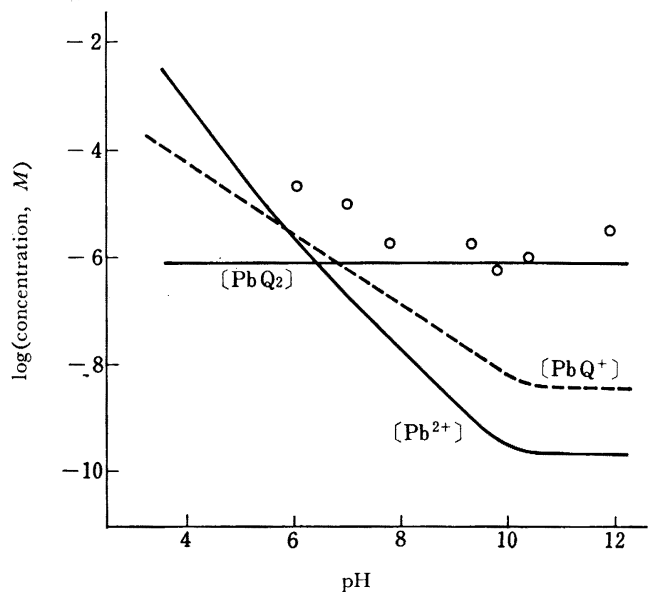

Fig. 1 Concentration curves of various species of lead 8-hydroxyquinolate vs. $\mathrm{pH}$

O Solubility of lead 8-hydroxyquinolate measured by the atomic absorption method

Table I Solubilities of lead 8-hydroxyquinolate in water at various temperatures

\begin{tabular}{cccc}
\hline \multirow{2}{*}{ No. } & \multicolumn{3}{c}{ Solubility $(\mu \mathrm{g} \mathrm{Pb} / 100 \mathrm{ml})$} \\
\cline { 2 - 4 } & $25^{\circ} \mathrm{C}$ & $50^{\circ} \mathrm{C}$ & $80^{\circ} \mathrm{C}$ \\
\hline 1 & 60.1 & 214.5 & 643.5 \\
2 & 62.2 & 219.0 & 605.0 \\
3 & 58.4 & 213.5 & 607.5 \\
Average & 60.2 & 215.7 & 618.7 \\
\hline
\end{tabular}

Table I で明らかなように, 温度の上昇とともに溶解度 は著しく増加している.

\section{2 沈殿の熟成効果}

$31.7 \mathrm{mg}$ の鉛を $\mathrm{pH} 10$ で 8-ヒドロキシキノリンを 用いる常法により室温で沈殿させ，母液中に種々の時間 放置したのち沪過し，沪液中の 鉛量を測定したところ Fig. 2 のようになった. 4 時間放置後沪液中の鉊の量は 一定となり鉛の溶解損失量は約 $80 \mu \mathrm{g} \mathrm{Pb} / 100 \mathrm{ml}$ とな った。

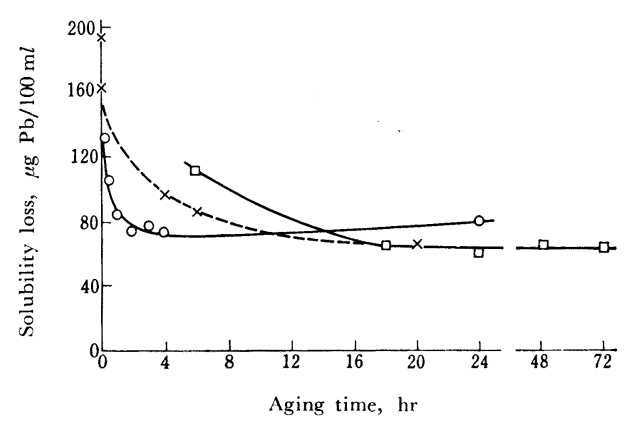

Fig. 2 Effect of aging on the precipitation of lead 8-hydroxyquinolate

O Precipitation by the conventional method; $\square$ Precipitation from homogeneous solution at room temperature; $\times$ Precipitation from homogeneous solution at $60^{\circ} \mathrm{C}$

鉛 8-ヒドロキシキノレートは $100^{\circ} \mathrm{C}$ 以下の水中で も数十度以上では結唱水を失うおそれがあるといわれ る9). 脱水すれば熟成効果が少なくなると考えられるの で沈殿生成はすべて室温で行なった，常法では生成する 沈殿が微細なため溶解度が大きく熟成により粒子が成厓 し，また後述するように転移もおこり溶解度は小さくな り沪過しやすくなる。

$31.7 \mathrm{mg}$ の鉛に対して PFHS 法で室温で长時間反応 させ，なたは $60^{\circ} \mathrm{C} て ゙ 2$ 時間反応させ 種々の時間放置 後，沪液中の鉛量を測定した結果を同じくFig. 2 に示 した. 室温では 8-アセトキシキノリンの加水分解速度 が小さいため10)，1 夜放置して及応を完結させると沪液 中の鉛の量は一定となり，溶解損失量は約 $60 \mu \mathrm{g} \mathrm{Pb} /$ $100 \mathrm{ml}$ となった. $60^{\circ} \mathrm{G}$ に 2 時間保つと 8-アセトキシ キノリンの加水分解はほとんど完了するのでその直後お よび，4 時間， 6 時間，20 時間後沪液中の 鉛量を測定 したところ，6 時間以上経過して溶解損失量が $85 \mu \mathrm{g}$ $\mathrm{Pb} / 100 \mathrm{~m} l$ となった. 高温で沈殿を生成すれば一部沈 殿が脱水され熟成効果が遅れることが明らかである。ま 
たPFHS 法では及结間を有效に使朋するため以後空 温で 1 液放置する方法を用いた。

\section{3 沈殿剤 8-ヒドロキシキノリン添加量の効果}

$31.7 \mathrm{mg}$ の鉛に対して $\mathrm{pH} 10$ で種々の量の 8-ヒドロ キシキノリン溶液を加えて沈殿を生成させ，沪液中の鉛 量を測定すると Table II のようになった. Table II に 示したように，多量の 8-ヒドロキシキノリンは溶解作 用をもつ倾们がみられるが，後述するように少量の鉛の 定量のためには，このような絬果にもかかわらずかなり 多量の 8-ヒドロキシキノリンを加える必要があること などから，鎴と 8-ヒドロキシキノリンの間に，後者が 過剩の条件で可溶性鉷塩を形成する傾向があるとすれば がり複雑な問题になるので，これに関しては他の金属 オキシネートとともに別に検討したい.

Table II The effect of quantity of 8-hydroxyquinoline on the solubility loss of lead 8-hydroxyquinolate

\begin{tabular}{ccc}
\hline $\begin{array}{c}\text { Pb taken } \\
(\mathrm{mg})\end{array}$ & $\begin{array}{c}\text { HQ† solution added } \\
(\mathrm{m} l)\end{array}$ & $\begin{array}{c}\text { Solubility loss } \\
(\mu \mathrm{g} \mathrm{Pb} / 100 \mathrm{~m} l)\end{array}$ \\
\hline 31.7 & 3.3 & 63 \\
31.7 & 3.3 & 65 \\
31.7 & 4.5 & 63 \\
31.7 & 4.5 & 67 \\
31.7 & 5.7 & 64 \\
31.7 & 5.7 & 62 \\
31.7 & 7.0 & 97 \\
31.7 & 7.0 & 102 \\
31.7 & 9.2 & 107 \\
31.7 & 9.2 & 132 \\
\hline
\end{tabular}

† 8-Hydroxyquinoline

\section{4 鉛 8-ヒドロキシキノレート沈殿に対する pH の 影響}

$31.7 \mathrm{mg}$ の鉛に対して種々の $\mathrm{pH}$ で常法により鉛 8ヒドロキシキノレート沈殿をつくり沪液中の鉛を定量し た結果を Fig. 3 に示す. Fig. 3 より常法によれば pH 8〜12 の範囲で定量的に沋殿することがわかる.なお，

Fig. 3 の結果は Fig. 1 に示した種々の pH における溶 解度の関係とその傾向が一致しており, 沈殿母液中に溶 存している鉛の濃度は $10^{-6} \mathrm{~mol} / l$ のけたである.

PFHS 法による場合には鉛 $10.0 \mathrm{mg}$ に対して $\mathrm{pH}$ 5〜13 の範囲にわたって重量分析した結果を Table III に示した. この際 $\mathrm{pH} 7.5 \sim 12.0$ の範囲で定量的な沈 殿が生成した．PFHS 法によれば沈殿の結晶が常法に 比べて大きくなるため常法よりも低い $\mathrm{pH}$ から定量的な 沈殿が得られるものと考えられる。

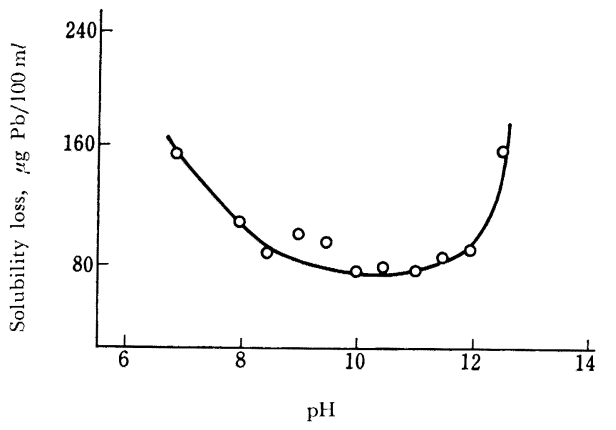

Fig. 3 Effect of $\mathrm{pH}$ on the solubility loss of lead 8-hydroxyquinolate prepared by the conventional method

Table III Precipitation of lead 8-hydroxyquinolate from homogeneous solution at various $\mathrm{pH}^{\prime} \mathrm{s}$

\begin{tabular}{cccc}
\hline $\mathrm{Pb}$ taken $(\mathrm{mg})$ & $\mathrm{pH}$ & Pb found $(\mathrm{mg})$ & Difference $(\mathrm{mg})$ \\
\hline 10 & 5.0 & 0 & -10.0 \\
10 & 5.5 & 0 & -10.0 \\
10 & 6.0 & 0 & -10.0 \\
10 & 6.5 & 3.30 & -6.70 \\
10 & 7.0 & 9.45 & -0.55 \\
10 & 7.5 & 9.91 & -0.09 \\
10 & 8.0 & 9.99 & -0.01 \\
10 & 8.5 & 9.95 & -0.05 \\
10 & 9.0 & 9.99 & -0.01 \\
10 & 9.5 & 9.95 & -0.05 \\
10 & 10.0 & 9.99 & -0.01 \\
10 & 11.0 & 9.95 & -0.05 \\
10 & 11.5 & 9.95 & -0.05 \\
10 & 12.0 & 9.99 & -0.01 \\
10 & 12.5 & 9.28 & -0.72 \\
10 & 13.0 & 1.00 & -9.00 \\
\hline
\end{tabular}

\section{5 沈殿の組成および乾燥温度}

鉛 $10.0 \mathrm{mg}$ をとり $\mathrm{pH} 10$ で常法执よび PFHS 法 で鉛 8-ヒドロキシキノレート沈殿を生成させ，ガラス 沪過器で沪過洗浄したのち室温, $105 \sim 110^{\circ} \mathrm{C}, 130^{\circ} \mathrm{C} \pm$ $5^{\circ} \mathrm{C}, 150^{\circ} \mathrm{C} \pm 5^{\circ} \mathrm{C}$ の各温度で恒量になるまで順次乾燥 した場合の結果を Table IV に示す.

沈殿の組成は $\mathrm{Pb}\left(\mathrm{C}_{9} \mathrm{H}_{6} \mathrm{NO}\right)_{2} \cdot 2 \mathrm{H}_{2} \mathrm{O}$ であり，105〜 $110^{\circ} \mathrm{C}$ で乾燥することにより定量的に無水物となる. 多 くの 2 估金属の 8-ヒドロキシキノレートは 2 分子の結 晶水をもち， $130^{\circ} \mathrm{C}$ で無水物となる. 鉛 8-ヒドロキシ キノレートも 2 分子の結晶水をもっているが，その結合 力は弱く $110^{\circ} \mathrm{C}$ で完全に脱水される.

鉛 8-ヒドロキシキノレート沈殿の乾燥は上に述べた ように $105 \sim 110^{\circ} \mathrm{C}$ で重量分析的に満足できるが，沈殿 の乾燥を高周波乾燥によって行なうとさらに満足すべき 
Table IV Drying of the precipitate of lead 8-hydroxyquinolate

\begin{tabular}{cccccc}
\hline \multirow{2}{*}{$\begin{array}{c}\text { Precipitation } \\
\text { method }\end{array}$} & $\begin{array}{c}\mathrm{Pb} \\
\text { taken } \\
(\mathrm{mg})\end{array}$ & $\begin{array}{c}\text { Room } \\
\text { temp. }\end{array}$ & $\begin{array}{c}105 \sim \\
110^{\circ} \mathrm{C}\end{array}$ & $\begin{array}{c}130^{\circ} \mathrm{C} \\
\pm 5^{\circ} \mathrm{C}\end{array}$ & $\begin{array}{c}150^{\circ} \mathrm{C} \\
\pm 5^{\circ} \mathrm{C}\end{array}$ \\
\cline { 3 - 6 } Conventional & 10.0 & 24.5 & 24.0 & 23.6 & - \\
" & 10.0 & 25.3 & 23.4 & 23.2 & - \\
" & 10.0 & 25.2 & 23.8 & 23.4 & - \\
" & 10.0 & - & 23.9 & 23.6 & 23.6 \\
" & 10.0 & - & 23.8 & 23.5 & 23.5 \\
" & 10.0 & - & 23.8 & 23.5 & 23.5 \\
" & 10.0 & - & 23.8 & 23.4 & 23.4 \\
PFHS & 10.0 & 25.2 & 23.9 & 23.3 & - \\
" & 10.0 & 25.3 & 24.0 & 23.5 & - \\
" & 10.0 & 25.5 & 24.0 & 23.5 & - \\
" & 10.0 & - & 23.8 & 23.4 & 23.3 \\
" & 10.0 & - & 23.9 & 23.4 & 23.4 \\
" & 10.0 & - & 23.9 & 23.6 & 23.6 \\
" & 10.0 & - & 23.9 & 23.6 & 23.6 \\
\hline
\end{tabular}

Theoretical values of lead 8-hydroxyquinolate for $10.0 \mathrm{mg}$ of lead $\mathrm{Pb}\left(\mathrm{C}_{9} \mathrm{H}_{6} \mathrm{NO}\right)_{2} \cdot 2 \mathrm{H}_{2} \mathrm{O}: 25.65 \mathrm{mg}$, $\mathrm{Pb}\left(\mathrm{C}_{9} \mathrm{H}_{6} \mathrm{NO}\right)_{2} \cdot \mathrm{H}_{2} \mathrm{O}: 24.78 \mathrm{mg}$, $\mathrm{Pb}\left(\mathrm{C}_{9} \mathrm{H}_{6} \mathrm{NO}\right)_{2} \quad: 23.91 \mathrm{mg}$

結果が得られた. $0.01 M(f=0.9796)$ の鉛溶液 10.00 $\mathrm{ml}$ をとり $\mathrm{pH} 9$ で常法および PFHS 法で 8-ヒドロキ シキノレート沈殿を生成させ, ガラス沪過器で沪過洗浄 する. ここに用いるガラス沪過器およびその後の沈殿の 乾燥は次のようにした. 電子レンジ中にガラス沪過器を 入れ, 20 分間高周波照射をしてデシケーター中に 20 分 間保ったのちひょう量する.この操作を恒量值を得るま でくりかえす. ガラス沪過器は 20 分間の高周波照射で じゅうぶん乾燥できたが，2回照射をくりかえして恒量 值を確認した・沈殿の乾燥は Table V に示したように 常法によるものでは 20 分間の高周波照射でじゅうぶん 乾燥するが， 2 回乾燥して恒量值を得た. PFHS 法によ るものでは沈殿粒子が粗大であるため, 常法によるもの よりも脱水しにくく, Table Vに示したように 20 分間 の高周波照射を 3 回以上くりかえして恒量值を得た.い

Table V Drying of lead 8-hydroxyquinolate precipitate by means of the irradiation of high frequency waves (Drying in an electronic range)

\begin{tabular}{ccccccc}
\hline \multirow{2}{*}{$\begin{array}{c}\text { Time of drying } \\
(\text { min })\end{array}$} & \multicolumn{4}{c}{ Weight of precipitate $(\mathrm{mg})$} \\
\cline { 2 - 5 } & \multicolumn{2}{c}{ Conventional } & \multicolumn{4}{c}{ PFHS } \\
\hline 20 & 48.6, & 48.5, & 48.6 & 49.3, & 49.6, & 49.6 \\
20 & 48.6, & 48.5, & 48.6 & 48.7, & 49.3, & 48.7 \\
20 & & & & 48.6, & 48.6, & 48.6 \\
20 & & & & 48.6, & 48.6, & 48.6 \\
20 & & & 48.6, & 48.6, & 48.6 \\
\hline
\end{tabular}

Theoretical value as $\mathrm{Pb}\left(\mathrm{C}_{9} \mathrm{H}_{6} \mathrm{NO}\right)_{2}: 48.54 \mathrm{mg}$
ずれの場合にも得られた恒量值は鉛 8-ヒドロキシキノ レートの無水物の理論值とよく一致している. したがっ て, 沈殿を電子レンジで乾燥することは常法による 105 $\sim 110^{\circ} \mathrm{C}$ の乾燥に相当し, きわめて短時間に付着水およ び鉛 8-ヒドロキシキノレートの場合の結晶水の脱水が 可能で, 重量分析に際しての沈殿の乾燥操作がきわめて 容易に行なわれることが判明した.

\section{6 定量的な鉛 8-ヒドロキシキノレート沈殿の生成} 範囲

鉛 8-ヒドロキシキノレートは上に述べてきたように 室温で沈殿を生成し, じゅうぶえ熟成したのち沪過, 洗 浄し， $105 \sim 110^{\circ} \mathrm{C}$ で乾燥することにより重量分析が可 能であることがわかったが，この方法で定量できる鉛の 量を求めると Table VI のようになった. ただし, 沈 殿を生成すべき溶液の全体積を $100 \mathrm{~m} l$ とした場合であ り,この体積は $200 \mathrm{~m} l$ 程度までは増大できるが，体積 を増加し，また鉛量を増加すると沈殿試薬が多量必要と なり，その際はかえって沈殿剤の溶媒であるアルコール やアセトンによる沈殿の溶解度の増加をきたすおそれが あり，本実験における程度の鉛量および液量が分析に対 しては適当と考えられる.

常法によれば 2〜50 mg, PFHS 法では 5〜50 mg の 鉛が重量分析できる. PFHS 法では試薬と共存する時間 が長く，鉛が微量になると過剩に存在する 8-ヒドロキ

Table VI Gravimetric determination of lead 8-hydroxyquinolate

\begin{tabular}{|c|c|c|c|}
\hline $\begin{array}{l}\text { Precipitation } \\
\text { method }\end{array}$ & $\begin{array}{l}\text { Pb taken } \\
(\mathrm{mg})\end{array}$ & $\begin{array}{l}\mathrm{Pb} \text { found } \\
\text { (mg) }\end{array}$ & $\begin{array}{l}\text { Difference } \\
\quad(\mathrm{mg})\end{array}$ \\
\hline Conventional & 2.1 & 2.0 & -0.1 \\
\hline$"$ & 4.2 & 4.0 & -0.2 \\
\hline "I & 10.5 & 10.5 & 0 \\
\hline " & 21.1 & 20.9 & -0.2 \\
\hline " & 31.7 & 31.4 & -0.3 \\
\hline " & 42.2 & 42.4 & +0.2 \\
\hline "I & 52.8 & 52.7 & -0.1 \\
\hline PFHS & 1.0 & 0.6 & -0.4 \\
\hline " & 1.0 & 0.7 & -0.3 \\
\hline " & 2.0 & 1.7 & -0.4 \\
\hline " & 2.0 & 1.6 & -0.2 \\
\hline "I & 5.0 & 4.8 & -0.2 \\
\hline "I & 5.0 & 4.8 & -0.1 \\
\hline " & 10.0 & 9.9 & -0.1 \\
\hline " & 10.0 & 9.9 & -0.1 \\
\hline " & 20.0 & 19.8 & -0.2 \\
\hline " & 20.0 & 19.8 & -0.2 \\
\hline "I & 30.0 & 30.0 & 0 \\
\hline " & 30.0 & 30.2 & +0.2 \\
\hline " & 50.0 & 50.1 & +0.1 \\
\hline " & 50.0 & 49.9 & -0.1 \\
\hline
\end{tabular}


シキノリンの影響をうけて一度定量的に生成した沈殿が いくぶん溶解するため $2 \mathrm{mg}$ 程度の鉛が定量できないも のと考えられる.

\section{7 鉛 8-ヒドロキシキノレート沈殿に対する共存イ オンの影響}

共存不純物として銅, 严鉛, カドミウムおよびビスマ スについて検討した.これらの不純物は鉛と混合してい る場合に鉛より優先して沈殿する. そこでこれらのイオ ンを銅は $\mathrm{pH} 4$ で，亜鉛は $\mathrm{pH} 5$ で，カドミウムおよ びビスマスは pH 5.5 でそれぞれ 8-ヒドロキシキノレ 一トとしてあらかじめ 沈殿除去したのち, 鉛 8-ヒドロ キシキノレートを沈殿させ, いずれも重量分析した. 結 果を Table VII に示す.

Table VII Separation of lead from diverse ions

\begin{tabular}{|c|c|c|c|c|c|}
\hline \multirow{2}{*}{$\begin{array}{l}\text { Precipitation } \\
\text { method }\end{array}$} & \multirow{2}{*}{$\begin{array}{l}\text { Pb taken } \\
\quad(\mathrm{mg})\end{array}$} & \multicolumn{2}{|c|}{ Diverse ion } & \multicolumn{2}{|c|}{ Found (mg) } \\
\hline & & Ion & $\begin{array}{l}\text { Taken } \\
\text { (mg) }\end{array}$ & $\begin{array}{c}\text { Diverse } \\
\text { ion }\end{array}$ & $\mathrm{Pb}$ \\
\hline Conventional & 10.0 & $\mathrm{Cu}$ & 10.0 & 10.0 & 10.0 \\
\hline " & $" \prime$ & "I & " & 10.0 & 10.0 \\
\hline PFHS & " & " & " & 10.0 & 10.0 \\
\hline$" 1$ & " & " & " & 10.0 & 10.0 \\
\hline Conventional & 10.0 & $\mathrm{Zn}$ & 10.0 & 10.6 & 9.2 \\
\hline " & $" \prime$ & "I & " & 10.3 & 9.4 \\
\hline PFHS & " & " & " & 10.0 & 10.0 \\
\hline " & " & " & " & 10.1 & 9.9 \\
\hline Conventional & 10.0 & $\mathrm{Cd}$ & 10.0 & 10.2 & 10.8 \\
\hline " & " & " & " & 10.3 & 8.4 \\
\hline PFHS & $"$ & " & " & 9.9 & 9.9 \\
\hline " & " & " & " & 9.8 & 9.9 \\
\hline Conventional & 10.0 & $\mathrm{Bi}$ & 10.0 & 13.7 & 8.8 \\
\hline "I & " & " & " & 13.8 & 8.6 \\
\hline PFHS & 5.0 & "I & " & 10.5 & 4.5 \\
\hline " & " & " & " & 10.6 & 4.3 \\
\hline
\end{tabular}

銅と鉛の混合溶液から銅 8-ヒドロキシキノレートを PFHS 法で沈殿させると $\mathrm{pH} 5$ 付近では鉛はまったく 共沈殿しない11). 亜鉛については常法では鉛との分離は よくないが, PFHS 法では満足すべき分離ができる.

カドミウムと鉛の混合溶液からカドミウムを沈殿させ ると鉛がかなり共沈殿するが7)，PFHS 法によれば $\mathrm{pH}$ 5.5 でからうじて両者を分離しうる. ビスマスについて はすでに発表したように，ビスマス 8-ヒドロキシキノ レートは鉛をきわめて共沈殿しやすく，8-ヒドロキシキ ノレートとして相互に 1 回の沈殿操作で完全に分離する ことは不可能である12).

\section{8 鉛 8-ヒドロキシキノレート沈殿の結晶核} 沈殿の結晶核発生に関する Nielsen らの理論 ${ }^{13)}$ を引
用して, 結晶核の発生速度が過飽和濃度 $C_{0}$ の $p$ 乗に比 例するとして積分した形を示すと次のようになる.

$$
T_{\alpha} C_{0}^{p-1}=K_{\alpha}
$$

ここに $T_{\alpha}$ は沈殿発生の誘導期間 とおくことができ る. 両辺の対数をとれば次式を得る.

$$
\log T_{\alpha}=\log K_{\alpha}-(p-1) \log C_{0}
$$

さて, $0.001 M$ の鉛溶液 $2 \sim 14 \mathrm{ml}$ を光度滴定装置のビ 一カーにとり最終体積が $50 \mathrm{ml}$ になるように水を加え, $\mathrm{pH} 10$ の緩衝液を加えビーカーを装置中に入れ，上部 に $25^{\circ} \mathrm{C}$ の水を循環させ $340 \sim 420 \mathrm{~m} \mu$ のフィルターを 使用して吸光度を 0 としたのち，0.01M 8-ヒドロキシ キノリン酶酸溶液 $2 \mathrm{ml}$ を注射器ですばやく加え, ただ ちに吸光度の 变化を 5 秒ごとに測定して吸光度の急変 点までの時間を求め $T_{\alpha}$ とした. 過飽和濃度 $C_{0}$ とし ては鉛および 8-ヒドロキシキノリンの初濃度を用い, $\left[\mathrm{Pb}^{2+}\right]\left[\mathrm{Q}^{-}\right]^{2}$ というイオン積を用いた。実験結果を Fig. 4 に示す. Fig. 4 より $\log T_{\alpha}$ と $\log C_{0}$ の間には 直線関係が成立し，その傾斜は 2 となり，したがって $p=3$ となった. 鉛オキシネート分子の 3 番めの分子が 律速分子となり, 結晶核は鉛オキシネート分子 2 分子よ りなると考えられる。

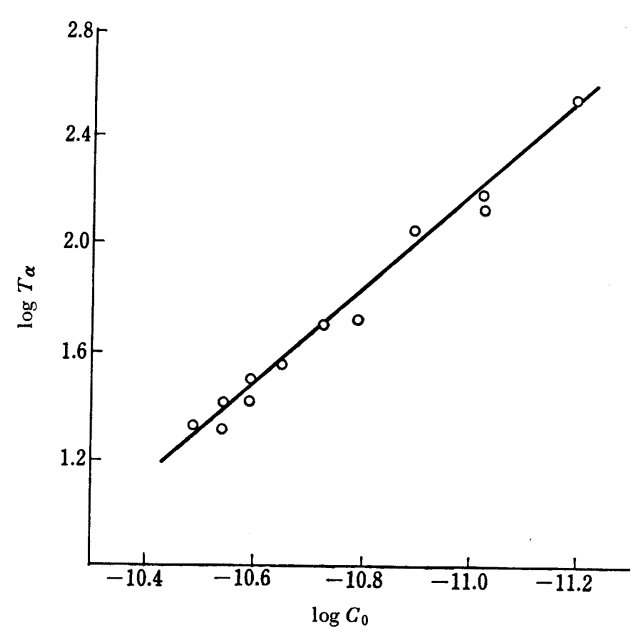

Fig. 4 Plots of logarithms of induction periods vs. logarithms of supersaturated concentrations for the precipitation of lead 8hydroxyquinolate

\section{9 鉛 8-ヒドロキシキノレート沈殿粒子の形態}

鉛 8-ヒドロキシキノレート沈殿の 結晶化学的特徵に 関しては一部予報として発表したが3)，その詳細を示す. 


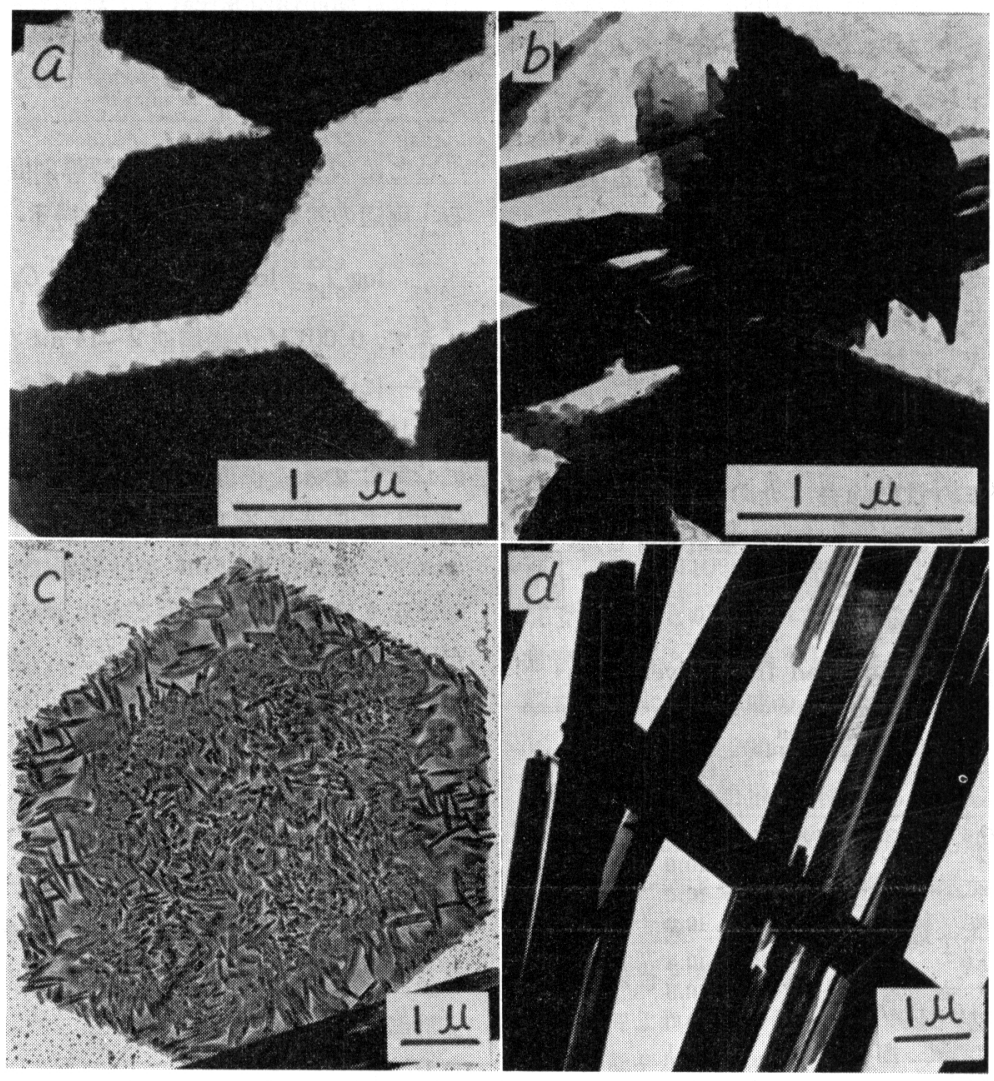

Fig. 5 Electron micrographs of lead 8-hydroxyquinolate

a, b, c : Prepared by the conventional method; d : Prepared by PFHS method

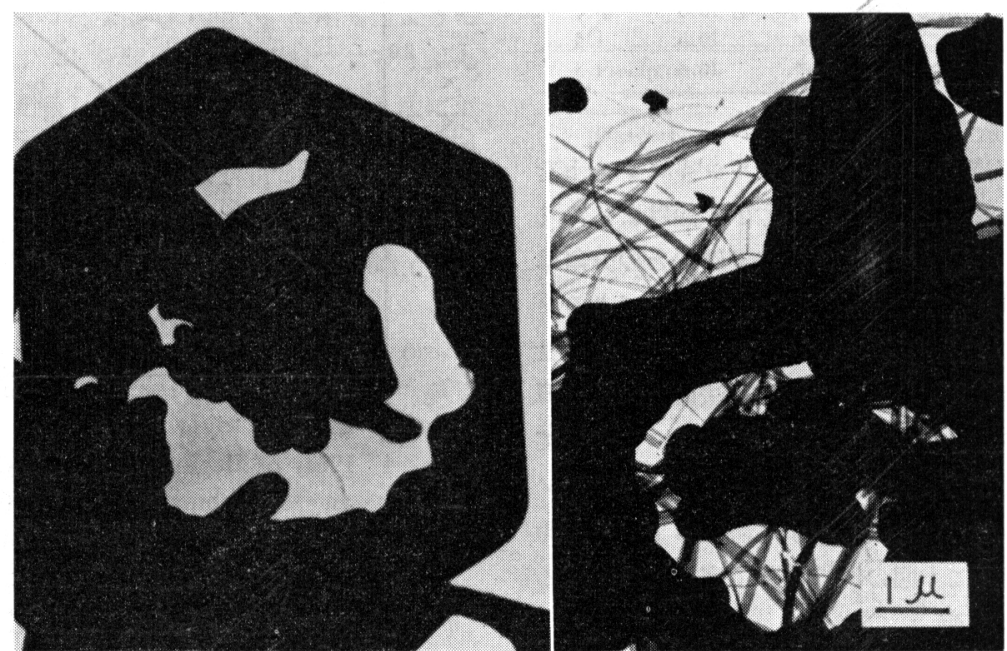

Fig. 6 Dissolution process of hexagonal lamellar crystals of lead 8-hydroxyquinolate 


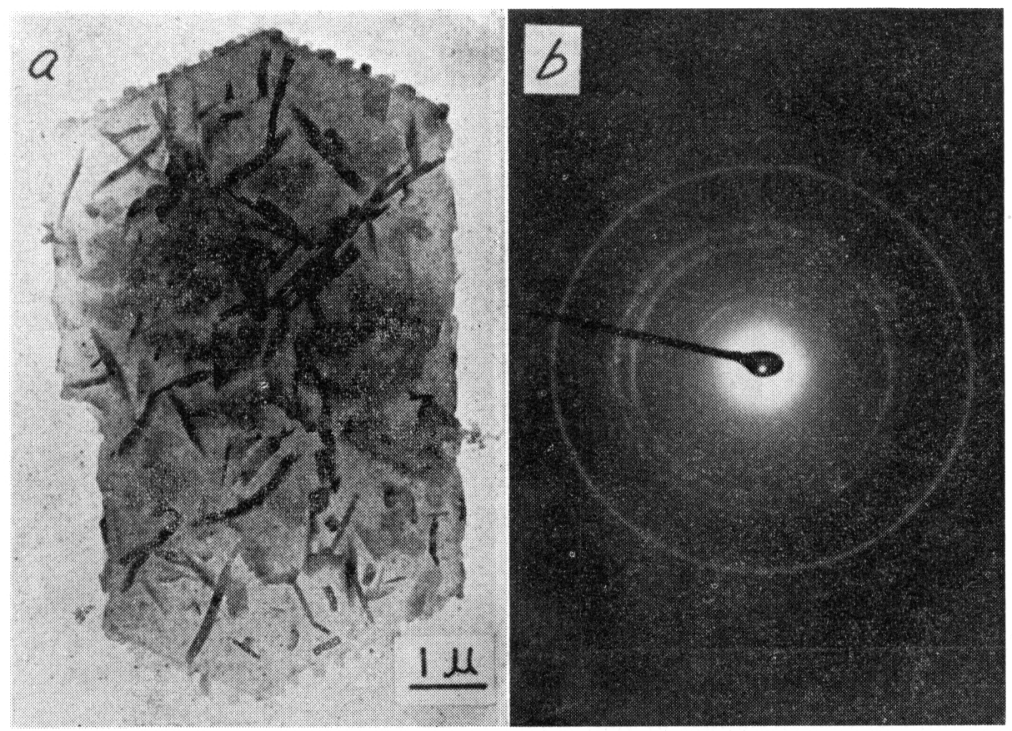

Fig. 7 Electron micrograph (a) and its selected area electron diffraction diagram (b) of hexagonal lamellar crystal of lead 8-hydroxyquinolate

沈殿の電子顕微鏡写真を Fig. 5 亿示寸. 沈殿粒子は最 終的には汪とんどすべて針状結晶となるが，常法で生成 した場合にはその初期に Fig. 5 a に示したように六角 形またはひし形の薄片結晶を生じ，時間の経過とともに Fig. 5 b 亿示したように針状結晶が混在し，数分後には すべて針状結晶となる。PFHS 法で沈殿を生成させると その初期にわずかに六角板状結晶を生成する場合もある が，ほとんど反応初期から針状結晶を生じ，反応の進行 につれて Fig. 5 d に示すような長い針状結晶へと成長す る.なお，沈殿中に生成した六角板状粒子は Fig. 5 c に 示したように粒子中にさらに微粒子を含えでいる場合が かなり観察される。この微粒子は針状結晶へ成長する直 前の核ともいうべき粒子と考元られる。 また常法で沈殿 生成を冷蔵庫中の低温で行なった場合にはかなり形の整 った六角板状の結晶を生ずるが，この場合にはFig. 6 に 示したように結晶が溶解していく様子が観測される。そ こで板状結晶から針状結晶への变化は不安定な板状結晶 の溶解，そして安定な針状結晶の析出という過程をとる もので板状結晶上の粒子は部分的な溶解, 析出によって 析出しはじめた針状結晶の核か, 板状結晶が生成すると きその表面に針状絬晶の初期過程のものが析出したかに よって発生したものと推定される.

銅 8-ヒドロキシキノレートは鉛 8-ヒドロキシキノレ 一トとほとえど同様の形態を有する板状結晶と針状結晶 を生成するが，その際板状結晶が針状結晶より安定で熟 成中すべて板状結晶に変化する11). カドミウム 8-ヒド
ロキシキノレートも針状結晶と板状結晶を生ずるが板状 結晶が安定である7)、鉛 8-ヒドロキシキノレートはこれ らと粒子の形態変化の様子が異なっている.

\subsection{0 鉛 8-ヒドロキシキノレート板状結晶の構造}

鉛 8-ヒドロキシキノレートの板状結晶はきわぬて不 安定であるためX線回折操作在するほど多量に純粋な状 態で生成することは不可能であり，また電子顕微鏡中で は Fig. 7 に示したように, 脱水されて 無水状態となる とともに結晶構造が变化するため板状結晶の結晶構造は 解析さ秃ていない.しかし，銅 8-ヒドロキシキ/レー トの板状結晶ときわめてよく類似しているので，これと 同型と考光れば単斜晶系に属する結晶となる.

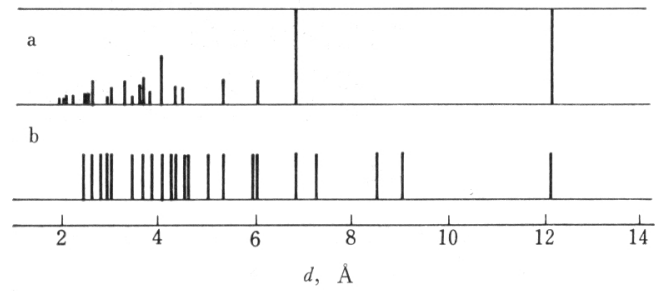

Fig. 8 X-Ray diffraction diagram obtained from needle crystals of lead 8-hydroxyquinolate (a) and spacings calculated (b)

3.11 鉛 8-ヒドロキシキノレート針状結晶の構造

鉛 8 -ヒドロキシキノレート沈殿安生成させ 1 夜熟成 


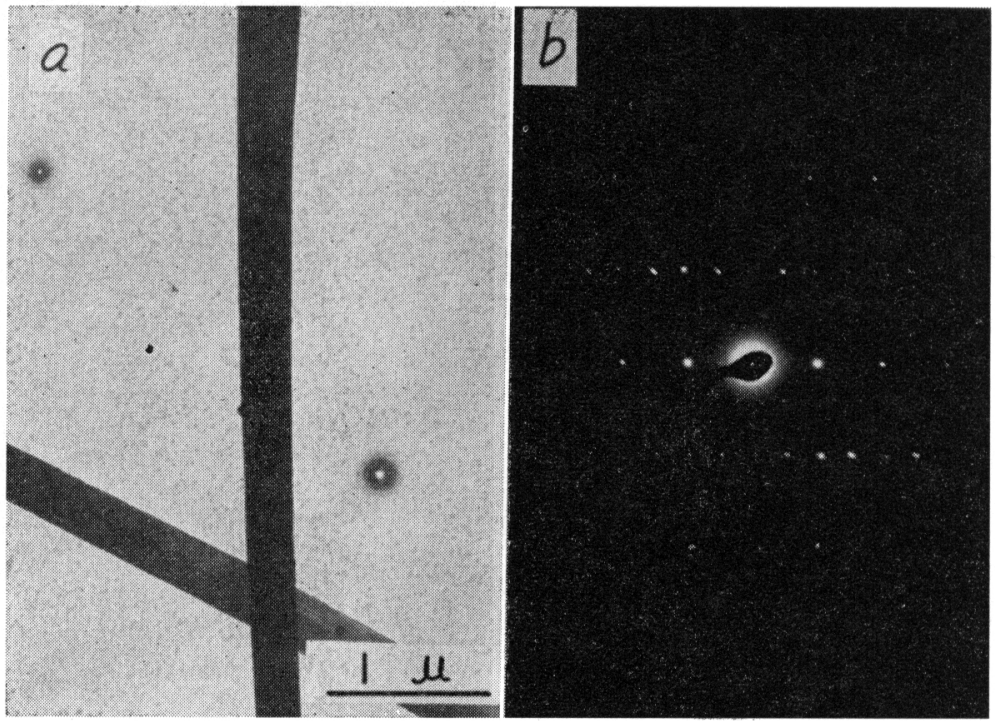

Fig. 9 Electron micrograph (a) and its selected area electron diffraction diagram (b) of needle crystal of lead 8-hydroxyquinolate

後沪過洗浄し，自然乾燥してX線回折法によって分析す ると Fig. 8 aのようになった. この結晶を正方晶系で格 子定数を $a_{0}=b_{0}=12.1, c_{0}=13.7$ と仮定して計算によ って面間隔求めると，Fig. $8 \mathrm{~b}$ に示すようになる。両 者がよく一致することにより，鉛 8-ヒドロキシキノレ 一トの針状結晶は正方晶系に属するものであると考光ら れる。

Fig. 9 には鉛 8-ヒドロキシキノレートの針状結晶の 電子回折像学示す. この結晶は繊維周期 $4.7 \AA$, 赤道上 の周期 $6.8 \AA$ 安示すが，上記 X 線回折の結果とまった く一致好ず無水物となって結晶構造の变化したものであ ると考えられる。無水物の結晶構造については銅8-ヒド ロキシキノレートについて水渡ら ${ }^{15) 16)}$ 方詳細な報告をし ているが，鉛 8-ヒドロキシキノレートについては本論 交の範囲外と考元て別に報告することにする。

$$
\left(\begin{array}{l}
1971 \text { 年 } 4 \text { 月, 日本化学会第 } \\
24 \text { 年会に扮いて一部発䘚 }
\end{array}\right)
$$

\section{交献}

1) H. Goto : Sci. Rept. Tohoku Univ., 1st Ser., 26, 391 (1937).

2) V. Marsson, L. W. Haare : Chem.-Ztg., 52, 993 (1928).

3) K. Takiyama, T. Kozen : J. Electron Microscopy, 21, 277 (1972).

4) E. D. Salesin, L. Gordon : Talanta, 4, 75 (1960).

5) 藤永太一郎, 関戸栄一訳：“イオン平衡”, $p$. 258 (1967), (化学同人).
6) 藤永太一郎，関戸栄一訳：同上，p. 154 (1967), (化学同人).

7）滝山一善, 幸前照美 : 本誌, 22, 291 (1973).

8) L. Erdey : "Gravimetric Analysis", Part III, p. 230 (1965), (Pergamon Press).

9) 関戸栄一：日化， 80，375 (1959).

10) 滝山一善，沢田美穂子，大谷信子：本誌， 19, 687 (1970).

11）谷川八千代，南 智子，滝山一善：同上， 14, 1055 (1965).

12) 滝山一善, 上月豰子：同上， 17，1412 (1968).

13) J. A. Christiansen A. E. Nielsen : Acta Chim. Scand., 5, 673, 674 (1951).

14) 関戸栄一：日化，78，1791 (1957).

15) E. Suito, M. Arakawa, T. Kobayashi : KolloidZ. Z. Polym., 212, 155 (1966).

16) E. Suito, M. Arakawa, T. Kobayashi : ibid., 213, 135 (1966).

\section{is}

Properties of lead 8-hydroxyquinolate precipitate. Kazuyoshi TAkiYama, Yachiyo TAnigawa and Terumi Kozen (Department of Home Science, Mukogawa Women's University, 6-46, Ikebiraki-cho, Nishinomiya-shi, Hyogo)

Many kinds of metal ions precipitate quantitatively with 8-hydroxyquinoline and are analyzed easily by the gravimetric method. Lead 8-hydroxyquinolate has not been recommended, however, because of its indefinite composition. The authors obtained the precipitate of lead 8-hydroxyquinolate quantitatively from homogeneous solution using 8-acetoxyquinoline, and found also that lead 8-hydroxyquinolate had the dimorphism. In this paper the formation of precipitate and the crystal chemistry of lead 8-hydroxyquinolate 
are described.

2 to $50 \mathrm{mg}$ of lead contained in $100 \mathrm{ml}$ were precipitated by mixing with 8 -hydroxyquinoline solution at $\mathrm{pH} 8.5 \sim 12.0$ followed by aging for 4 hours by the conventional method. 5 to $50 \mathrm{mg}$ of lead in $100 \mathrm{ml}$ were precipitated as 8-hydroxyquinolate from homogeneous solution by the slow hydrolysis of 8-acetoxyquinoline at $\mathrm{pH} 7.5 \sim 12.0$ followed by standing over night.

The solubility of lead 8-hydroxyquinolate in water and in the buffer solutions was measured by the atomic absorption method and the solubility product of lead 8-hydroxyquinolate was calculated as $K_{\text {sp }}=10^{-23.5}$. The concentrations of various species of lead 8-hydroxyquinolate at various $\mathrm{pH}$ 's were calculated as shown in Fig. 1 and the solubilities measured were almost agreed with the calculated values as shown also in Fig. 1. The solubility increased remarkably with increasing the temperature as shown in Table I. The solubility loss was decreased by aging of the precipitates as shown in Fig. 3. The solubility loss was increased by addition of large excess of 8-hydroxyquinoline as shown in Table II. The effect of $\mathrm{pH}$ on the precipitation of lead 8hydroxyquinolate was shown in Table III. The precipitate of lead 8-hydroxyquinolate had 2 moles of water of crystallization, having the composition of $\mathrm{Pb}$ $\left(\mathrm{C}_{9} \mathrm{H}_{6} \mathrm{NO}\right)_{2} \cdot 2 \mathrm{H}_{2} \mathrm{O}$, and the water was removed by drying at $105 \sim 110^{\circ} \mathrm{C}$. From these results the quantitative precipitation of lead 8-hydroxyquinolate was performed as described before and it could be weighed after drying at $105 \sim 110^{\circ} \mathrm{C}$ as $\mathrm{Pb}\left(\mathrm{C}_{9} \mathrm{H}_{6} \mathrm{NO}\right)_{2}$. The precipitate of lead 8-hydroxyquinolate can also be dried by means of the high frequency waves in an electronic range. The water of crystallization of lead 8-hydroxyquinolate can be removed by treating the precipitate in an electronic range more conveniently than the usual electric oven as shown in Table V.

It was found that the crystalline nucleous of lead 8hydroxyquinolate was composed of 2 molecules by the measurements of the relation of the induction period with the initial concentration.

Lead 8-hydroxyquinolate has the dimorphism such as crystallized as needle and hexagonal lamellar particles as shown in Fig. 5. During the precipitation process the hexagonal particles appeared at the initial stage. The needle crystals were more stable than the hexagonal crystals and all of the particles changed completely to the needle crystals during the aging of the precipitate in the mother liquid. The transformation of particles seems to be promoted by dissolution of particles as shown in Fig. 6. The hexagonal particles have fine structure on their surface as shown in Fig. 5c. The small particles seem to be nuclei which grow to the needle crystals. The crystal structure of the hexagonal particles is considered as the isomorphous with that of copper 8-hydroxyquinolate, but such particles could not be prepared without containing needle crystals and, therefore, the crystal structure of the hexagonal particles of lead 8-hydroxyquinolate could not be analyzed. The needle crystals were analyzed by the X-ray diffraction method and the unit cell of these crystals was tetragonal with $a_{0}=b_{0}=12.1$ and $c_{0}=13.7 \AA$.

(Received Oct. 27, 1972)

\title{
酸素ボンブ法によるリンの比色定量
}

\author{
楢崎 久武, 宮地 精, 海野 昭之*
}

(1972 年 10 月 30 日受理)

酸素ボンブ法によるリンの回収率の検討おょび実際の定量を行ない，次の結果を得た.

（1）酸素ボンブ法によるリンの回収率を上げるためには, ボンブ燃炡後, 内容物を別の容器に完全 に移して硝酸一過塩素酸処理を行なう必要がある.

（2）本法による回収率は平均 $95 \%$ であり，また本法による界面活性䎟中のリンの分析值る湿式法 によるとれの 95\% であった。

（3）本法の特徵は，分析值のばらつきは湿式法に比べて大きいが，湿式法では分解しにくく，また 乾式法では損失を生ずる試料を迅速に分解できることである. 